\title{
Qualitative parameters of sugarcane silages treated with urea and calcium oxide
}

\section{Parâmetros qualitativos de silagens de cana-de-açúcar tratadas com ureia e óxido de cálcio}

\author{
Susi Cristina dos Santos Guimarães Martins ${ }^{1 *}$; Gleidson Giordano Pinto Carvalho ${ }^{2}$; \\ Aureliano José Vieira Pires ${ }^{3}$; Robério Rodrigues Silva ${ }^{3}$; Laudi Cunha Leite ${ }^{4}$; \\ Fabiano Matos Pereira'; Álvaro Diego Soares Mota ${ }^{5}$; Isis Miranda Carvalho Nicory \\ Cláudia Horne da Cruz ${ }^{6}$
}

\begin{abstract}
The objective was to evaluate the fermentation parameters, chemical composition and fractionation of carbohydrates of sugarcane silages treated with urea and calcium oxide $(\mathrm{CaO})$. Upon ensiling, the treatments applied to the sugarcane were: $1 \%$ urea; $0.5 \%$ urea $+0.5 \% \mathrm{CaO}$; and $1 \% \mathrm{CaO}$, in relation to a control silage, without additive. The chemical additives (urea and $\mathrm{CaO}$ ) were added at ensiling, in an amount calculated based on the fresh matter (as is). A completely randomized design consisting of four treatments (silages) and nine replicates was adopted. The material was conditioned in PVC mini-silos for five months. At the end of the storage period, silos were weighed again and samples were collected to quantify the losses caused by fermentation, dry matter recovery, $\mathrm{pH}$, and ammonia nitrogen $\left(\mathrm{N}_{-} \mathrm{NH}_{3}\right)$ of the silages and to evaluate the chemical composition and fractionation of carbohydrates. The silage with $1 \% \mathrm{CaO}$ showed the highest recovery of dry matter, and in terms of carbohydrate fractionation, it showed the highest levels of soluble and potentially soluble carbohydrates. Addition of $1 \% \mathrm{CaO}$ during ensiling reduces the fermentation losses of sugarcane silages.
\end{abstract}

Key words: Chemical additives, dry matter recovery, ensiling

\section{Resumo}

Objetivou-se avaliar os parâmetros fermentativos, a composição química e o fracionamento de carboidratos das silagens de cana-de-açúcar tratadas com ureia e óxido de cálcio $(\mathrm{CaO})$. Na ensilagem, os tratamentos aplicados à cana foram $1 \%$ de ureia; $0,5 \%$ de ureia $+0,5 \%$ de $\mathrm{CaO}$; e $1 \%$ de $\mathrm{CaO}$, em comparação a uma silagem controle, sem aditivo. Os aditivos químicos (ureia e $\mathrm{CaO}$ ) foram adicionados no momento da ensilagem, em quantidade calculada com base na matéria natural. Utilizouse um delineamento inteiramente casualizado, composto de quatro tratamentos (silagens) e nove

${ }^{1}$ Zootecnistas, Instituto Federal do Norte de Minas Gerais, IFNMG, Campus Salinas, MG. E-mail: susicris2005@yahoo.com.br; fabianofns@yahoo.com.br

2 Zootecnista, Prof. Dr., Dept ${ }^{\circ}$ de Zootecnia, Universidade Federal da Bahia, UFBA, Salvador, BA. E-mail: gleidsongiordano@, yahoo.com.br

3 Zootecnistas, Profs. Drs., Universidade Estadual do Sudoeste da Bahia, UESB, Itapetinga, BA. E-mail: aurelianojvp@yahoo. com.br; rrsilvauesb@hotmail.com

${ }^{4}$ Zootecnista, Prof. Dr., Universidade Federal do Recôncavo da Bahia, UFRB, Cruz das Almas, BA. E-mail: laudi_leite@hotmail.com

${ }^{5}$ Eng $^{\circ} \mathrm{Agr}^{\mathrm{o}}$, Instituto Federal do Norte de Minas Gerais, IFNMG, Campus Salinas. MG. E-mail: alvaroagronomia@yahoo.com.br

${ }^{6}$ Discentes do Curso de Doutorado do Programa de Pós Graduação em Zootecnia, Universidade Federal da Bahia, UFBA, Salvador, BA. E-mail: isismcarvalho@yahoo.com.br; cauhorne@gmal.com

* Author for correspondence 
repetições. O material foi acondicionado em minissilos de PVC, durante cinco meses. Ao fim do período de armazenamento, foi feita uma nova pesagem e coletadas amostras, para quantificação das perdas decorrentes da fermentação, da recuperação de matéria seca, do $\mathrm{pH}$ e do nitrogênio amoniacal $\left(\mathrm{N}^{\left.-\mathrm{NH}_{3}\right)}\right.$ das silagens e para avaliação da composição química e do fracionamento de carboidratos. A silagem com $1 \%$ de $\mathrm{CaO}$ apresentou maior recuperação de matéria seca, e em relação ao fracionamento dos carboidratos apresentou maior teor de carboidratos solúveis e potencialmente solúveis. A adição de 1\% de $\mathrm{CaO}$ durante a ensilagem reduz as perdas fermentativas de silagens da cana-de-açúcar.

Palavras-chave: Aditivos químicos, ensilagem, recuperação de matéria seca

\section{Introduction}

In the last decade, the preservation of sugarcane as silage has aroused the interest of researchers and producers due to the benefits in logistics and operability of this technique. According to Amaral et al. (2009), there are several advantages of ensiling sugarcane; among them is the concentration of labor in a single period, which makes it possible to harvest all forage at once and clear the area prior to the beginning of the rainy season for a more uniform plant growth.

Thus, ensiling sugarcane has been indicated as an alternative to facilitate the management of canebrakes, since it allows for concentrating the cultivation activities, increasing field longevity by favoring a more uniform regrowth and improving the efficiency in the control of weeds (BALIEIRO NETO et al., 2007). Sugarcane in its natural, fresh form has a high percentage of soluble sugar; however, according to Pedroso et al. (2007), the major limitation in ensiling is the large production of ethanol, which results in low-quality forage. Undesirable fermentations in sugarcane silages, such as the alcoholic fermentation, result in considerable nutrient losses, which may affect the animal performance.

Studies aimed at reducing alcoholic fermentation and losses during the fermentation process in sugarcane silage (SANTOS et al., 2008; AMARAL et al., 2009; PEDROSO et al., 2011), e.g., the use of chemical additives at ensiling, may contribute to obtaining a better-quality roughage with greater nutritive potential for ruminant nutrition.
The objective was to evaluate dry matter losses, gas losses, fermentation characteristics, chemical composition and fractionation of carbohydrates of sugarcane silages treated with urea and/or calcium oxide.

\section{Materials and Methods}

The experiment was conducted at Instituto Federal do Norte de Minas Gerais (IFNMG) Campus Salinas. The municipality of Salinas is located in the north region of Minas Gerais State, Brazil (1609'12" S latitude, 42 18 '29"'W longitude and $475 \mathrm{~m}$ altitude). The average annual temperature and precipitation in the region are $22.4^{\circ} \mathrm{C}$ and 700 $\mathrm{mm}$, respectively (MACIEL et al., 2012).

The sugarcane (Saccharum officinarum L.) utilized was variety SP 79-1011, with average yield of $140 \mathrm{t} \mathrm{ha}^{-1} \mathrm{yr}^{-1}$ (as is), in the third cut. The plant was cut manually and disintegrated with the straws in a stationary shredder. Experimental mini-silos were made of PVC tubes with $40 \mathrm{~cm}$ in length and $10 \mathrm{~cm}$ diameter, provided with lids for proper sealing. A Bunsen-valve type was used to allow for the escape of the gases resulting from fermentation.

Three sub-samples were collected from each treatment to determine physical aspects and the chemical composition of the fresh sugarcane and of the silages after opening the mini-silos. The experimental design was completely randomized, with nine mini-silos for each type of silage: sugarcane silage without additives; sugarcane silage with $1 \%$ urea; sugarcane silage with $0.5 \%$ urea + $0.5 \% \mathrm{CaO}$; and sugarcane silage with $1 \% \mathrm{CaO}$. 
The chemical additive was added manually to the sugarcane after grinding. The material was subsequently conditioned in layers inside the minisilos and compacted using a pestle until it reached a density close to $700 \mathrm{~kg} / \mathrm{m}^{3}$ (fresh matter).

Dry sand $(150 \mathrm{~g})$ was placed at the bottom of each mini-silo, separated from the silage by a plastic screen, to collect effluents. The silos were weighed before ensiling (silo + lid + dry sand + screen $)$ and after they were filled and sealed, to quantify the gas losses and dry matter (DM) recovery, based on gravimetric differences. The mini-silos were closed in each ensiling (lids were sealed with adhesive tape), and kept in a covered site at ambient temperature until opening.

Mini-silos were opened after five months of stocking. Upon opening, the adhesive tapes for sealing were removed and the closed mini-silos were weighed again full. After the silage was removed, the tare was measured again to determine losses during fermentation.

After the mini-silos were weighed, the silage was removed and homogenized. One part was predried in an oven at $55{ }^{\circ} \mathrm{C}$ and the other was used to measure the $\mathrm{pH}$ and ammonia nitrogen $\left(\mathrm{N}-\mathrm{NH}_{3}\right)$ values, following the methodology described by Silva and Queiroz (2002).

Pre-drying was performed in a forced-ventilation oven at $55^{\circ} \mathrm{C}$ for 72 hours, and then the silage was processed to $1 \mathrm{~mm}$ in a Wiley mill. For the samples of the different sugarcane silages, the dry matter (DM), mineral matter (MM), ether extract (EE), crude protein $(\mathrm{CP})$, neutral detergent fiber corrected for ash and protein (NDFap), acid detergent fiber (ADF), cellulose (CEL), acid detergent lignin(ADL), neutral detergent insoluble nitrogen (NDIN), and acid detergent insoluble nitrogen (ADIN) contents were determined according to methodologies described by Silva and Queiroz (2002). The total carbohydrates (TC) were estimated according to Sniffen et al. (1992), as follows: TC $=100-(\% \mathrm{CP}$ $+\% \mathrm{EE}+\% \mathrm{MM})$.
Non-fibrous carbohydrates corrected for ash and protein (NFCap) were calculated as proposed by Hall (2003): NFCap = $100-[(\% \mathrm{CP}-\% \mathrm{CPU}+\% \mathrm{U})$ $+\mathrm{NDF} a \mathrm{p}+\% \mathrm{EE}+\% \mathrm{MM}]$

where CPU = crude protein from urea; and $\mathrm{U}=$ urea content. All terms were expressed as percentage of DM.

The concentration of neutral detergent fiber corrected for ash and protein effectively digestible for lactating cows was estimated according to Detmann et al. (2007), as: $\operatorname{NDFd}_{\mathrm{LC}} \%=0.67 \times$ $\left\{(\right.$ NDFap - L $\left.) \times\left[1-(\text { L/NDFap })^{0.85}\right]\right\}$, where NDFap is the neutral detergent fiber corrected for ash and protein and $\mathrm{L}$ is the lignin content (\% DM), estimated via sulfuric acid method (VAN SOEST; ROBERTSON, 1985).

The total digestible nutrients (TDN) contents of the feedstuffs was calculated according to the equation: $\mathrm{TDN}=\operatorname{adNFC} \%+\operatorname{adEE} \%+\operatorname{adCP} \%$ $+\mathrm{NDFd}_{\mathrm{VL}} \%$, in which the apparently digestible NFC content (adNFC) was estimated by the equation (DETMANN et al., 2006a): adNFC\% = 0.9507 NFCap $\%$ - 5.72 for lactating cows.

The apparently digestible EE content (adEE\%) was estimated by the equation (DETMANN et al., 2006b): $\operatorname{adEE} \%=0.8596 \mathrm{EE} \%-0.21$, for lactating cows.

The apparently digestible CP content (adCP\%) was estimated by the equation (DETMANN et al., $2006 \mathrm{c}): \operatorname{adCP} \%=0.7845 \mathrm{CP} \%-0.97$, for lactating cows.

The fractionation of total carbohydrates was performed as described by Azevedo et al. (2003), into fractions $\mathrm{A}+\mathrm{B} 1$, corresponding to the $\mathrm{NFC}$, neutral detergent soluble carbohydrates; $\mathrm{B} 2=\mathrm{TC}$ $(\mathrm{NFC}+\mathrm{iNDF})$, potentially soluble available fibrous carbohydrates; and $\mathrm{C}=\mathrm{iNDF}$, the neutral detergent indigestible fiber or insoluble fraction.

To evaluate the iNDF fraction (indigestible neutral detergent fiber), pre-dried composite samples of each silage were ground in a $2 \mathrm{~mm}$ 
sieve and conditioned individually in TNT (nonwoven fabric) bags, at a surface ratio of $20 \mathrm{mg}$ $\mathrm{DMcm}^{2-1}$. The bags were subsequently incubated for $240 \mathrm{~h}$ (CASALI et al., 2008) in the rumen of two cannulated $1 / 2$ Holstein $\times 1 / 2$ Gyr steers with an average body weight of $450 \mathrm{~kg}$ kept on Brachiaria decumbens Stapf. pastures. Each animal represented a replicate. After the incubation period, the bags were removed from the rumen, washed in running water until it was completely clear and subjected to extraction with neutral detergent (MERTENS, 2002), on autoclave $\left(100{ }^{\circ} \mathrm{C} 1^{-1}\right)$. The obtained residue was considered the $\mathrm{NDF}$ (DETMANN et al., 2001; DETMANN et al., 2007).

The gas losses were quantified in the silages after the mini-silos were opened, applying the equation proposed by Zanine et al. (2006): GL $=\{$ SWC $\mathrm{SWO} / \mathrm{FMC} \times \mathrm{DMC}\} \times 100$, where GL is the gas losses during storage ( $\%$ of the initial dry matter); SWC, the weight silo at ensiling; SWO, silo weight at opening; FMC, forage mass at ensiling; and DMC, the dry matter content of the forage at ensiling.

The dry matter recovery rate of the silage after the mini-silos were opened was determined by the method proposed by Jobim et al. (2007), according to the equation: $\mathrm{DMR}=\{\mathrm{FMO} \times \mathrm{DMO} / \mathrm{FMC}$ $\times \mathrm{DMC}\} \times 100$, in which DMR is the dry matter recovery rate; $\mathrm{FMO}$, the forage mass at opening; DMO, the dry matter content at opening; FMC, the forage mass at closure; and DMC, the forage dry matter content at closure.

The obtained data were subjected to analysis of variance using the SAEG statistical software, and Tukey's test was used to compare the means, when significant, at $5 \%$ probability.

\section{Results and Discussion}

The ammonia nitrogen $\left(\mathrm{N}-\mathrm{NH}_{3}\right)$ contents were highest $(\mathrm{P}<0.05)$ in the silages with urea and lower in the silages with calcium oxide and without additive (Table 1); however, they are within the levels considered normal, because maximum levels of 11 and $12 \%$ of the total nitrogen are suggested for silages with a good fermentation pattern (LOPES; EVANGELISTA, 2010). The ammonia nitrogen is associated with the fermentation quality of the silage, because it results from the degradation of the protein fraction by clostridia (McDONALD et al., 1991).

Table 1. Fermentation parameters of the sugarcane silages with urea and calcium oxide.

\begin{tabular}{lcccc}
\hline \multicolumn{1}{c}{ Silages } & $\mathrm{N}_{3}(\%$ total $\mathrm{N})$ & $\mathrm{pH}$ & Gas losses $(\% \mathrm{DM})$ & DM recovery $(\%)$ \\
\hline No additive & $3.88 \mathrm{~d}$ & $3.52 \mathrm{~d}$ & $11.11 \mathrm{a}$ & $77.26 \mathrm{c}$ \\
$1 \% \mathrm{UR}$ & $9.46 \mathrm{a}$ & $3.74 \mathrm{c}$ & $10.25 \mathrm{a}$ & $69.78 \mathrm{~d}$ \\
$0.5 \% \mathrm{UR}+0.5 \% \mathrm{CaO}$ & $6.56 \mathrm{~b}$ & $3.81 \mathrm{~b}$ & $5.49 \mathrm{~b}$ & $77.97 \mathrm{~b}$ \\
$1 \% \mathrm{CaO}$ & $4.95 \mathrm{c}$ & $4.09 \mathrm{a}$ & $5.83 \mathrm{~b}$ & $78.74 \mathrm{a}$ \\
$\mathrm{CV}(\%)$ & 10.97 & 1.21 & 9.19 & 0.30 \\
\hline
\end{tabular}

Means followed by equal letters in the column do not differ by Tukey's test at $5 \%$ significance.

$\mathrm{DM}=$ percentage of dry matter. No additive = sugarcane silage without additive; $1 \%$ UR = sugarcane silage with $1 \%$ urea; $0.5 \%$ $\mathrm{UR}+0.5 \% \mathrm{CaO}=$ sugarcane silage with $0.5 \%$ urea $+0.5 \% \mathrm{CaO} ; 1 \% \mathrm{CaO}=$ sugarcane silage with $1 \% \mathrm{CaO}$.

The additives influenced the $\mathrm{pH}$; however, $\mathrm{pH}$ values are adequate for preservation (McDONALD et al., 1991) of the ensiled material. The silage without additive showed the lowest $\mathrm{pH}$, which was predictable, since the sugarcane silage presents a low buffering capacity and a rapid drop in $\mathrm{pH}$.

The highest $\mathrm{pH}$ value was observed in the silage with $1 \% \mathrm{CaO}$. Addition of alkalinizing 
chemical additives, such as calcium oxide, interferes with the fermentation dynamics, altering the $\mathrm{pH}$ and osmotic pressure of the forage mass, and consequently inhibiting the development of undesirable microorganisms, especially epiphytic yeasts, during the fermentation of the sugarcane silage (AMARAL et al., 2009). These microorganisms tolerate low $\mathrm{pH}$ levels, which explains the high alcohol levels found in these silages (SANTOS et al., 2008).

The silage with $1 \%$ urea showed a higher $\mathrm{pH}$ in relation to that without additive, and lower $\mathrm{pH}$ as compared with the silages with $\mathrm{CaO}$. Lopes and Evangelista (2010) evaluated the fermentation characteristics of sugarcane silages enriched with $1.5 \%$ urea and observed high levels of $\mathrm{N}^{-\mathrm{NH}_{3}}$ (36.68\%) and $\mathrm{pH}$ (6.48). According to these authors, the greater amount of ammonia nitrogen in the silage with $1.5 \%$ urea explains the $\mathrm{pH}$ at silo opening. It should be stressed that the ammonia originating from the activity of urease on urea works as an inhibitor of yeast growth, which may reflect in fewer nutrient losses. In the present study, however, the ammonia produced seems not to have inhibited the yeasts in the silage with $1 \%$ urea, because this silage showed the lowest dry matter recovery. Moreover, the gas loss was the same as that of the silage without additive $(\mathrm{P}>0.05)$ and higher than that of silages with $1 \% \mathrm{CaO}$ and $0.5 \%$ urea $+0.5 \%$ $\mathrm{CaO}$. In regard to the fermentation parameters, the silage with $1 \%$ urea was inferior to the other silages given its higher concentration of $\mathrm{N}_{-} \mathrm{NH}_{3}$, its higher gas losses and total loss of DM, and lower DM recovery (Table 1).

The highest DM values were observed in the silages with $1 \% \mathrm{CaO}(24.99 \%)$ and $0.5 \%$ urea +
$0.5 \% \mathrm{CaO}(25.66 \%)$, and the lowest $(\mathrm{P}<0.05)$, in the silage with $1 \%$ urea $(20.96 \%)$ (Table 2$)$. These results corroborate reports of Amaral et al. (2009), who utilized calcium oxide (1\%) and limestone (1\%) in sugarcane silage and found higher DM values in relation to the silage without additive. In this study, the samples of fresh sugarcane from the silages without additive, with $1 \%$ urea, with $0.5 \%$ urea $+0.5 \% \mathrm{CaO}$ and with $1 \% \mathrm{CaO}$ showed DM contents of 28.3, 28.1, 31.33 and 30.05\%, respectively, before ensiling. Even though the DM values were lower in the silages without additives or with $1 \%$ urea, the values displayed at opening were lower than those obtained with addition of $\mathrm{CaO}$, which indicates loss of nutrients.

The organic matter content was the lowest $(\mathrm{P}<0.05)$ for the silage with $1 \% \mathrm{CaO}$ and highest for the silage without additive. The silage without $\mathrm{CaO}$ had a lower percentage of mineral matter, whereas those containing urea showed intermediate values of MM and consequently of OM.

The percentage of $\mathrm{CP}$ was higher $(\mathrm{P}<0.05)$ in the silage with $1 \%$ urea $(22.06 \%)$ as compared with the silage with $0.5 \%$ urea $+0.5 \% \mathrm{CaO}(9.31 \%)$, which resulted from the greater addition of non-protein nitrogen in this treatment. The silage without additive not from differ $(\mathrm{P}>0.05)$ from that with $1 \% \mathrm{CaO}$. Lopes and Evangelista (2010) found the lowest percentage of CP (12.33\%) in the sugarcane silage utilizing $1.5 \%$ urea, with $1 \%$ urea. Thus, the elevated $\mathrm{CP}$ content in the silage with $1 \%$ in this study differs from the values found in the literature, so we can infer that some problem related to the sampling of this silage may have contributed to this result, e.g. the poor drainage of the effluents, which increased the nitrogen concentration. 
Table 2. Chemical composition of sugarcane silages with urea and calcium oxide.

\begin{tabular}{lccccc}
\hline & \multicolumn{5}{c}{ Sugarcane silages } \\
\hline \multicolumn{1}{c}{ Item } & No additive & $1 \% \mathrm{UR}$ & $0.5 \% \mathrm{UR}+0.5 \% \mathrm{CaO}$ & $1 \% \mathrm{CaO}$ & $\mathrm{CV}(\%)$ \\
\hline $\mathrm{DM}^{1}$ & $22.58 \mathrm{~b}$ & $20.96 \mathrm{c}$ & $25.66 \mathrm{a}$ & $24.91 \mathrm{a}$ & 2.75 \\
$\mathrm{OM}^{1}$ & $95.08 \mathrm{a}$ & $93.99 \mathrm{~b}$ & $93.62 \mathrm{~b}$ & $90.50 \mathrm{c}$ & 0.69 \\
$\mathrm{MM}^{1}$ & $4.92 \mathrm{c}$ & $6.00 \mathrm{~b}$ & $6.38 \mathrm{~b}$ & $9.50 \mathrm{a}$ & 9.66 \\
$\mathrm{EE}^{1}$ & $1.47 \mathrm{~b}$ & $1.61 \mathrm{ab}$ & $1.75 \mathrm{ab}$ & $2.22 \mathrm{a}$ & 31.66 \\
$\mathrm{TC}^{1}$ & $89.33 \mathrm{a}$ & $70.33 \mathrm{~d}$ & $82.57 \mathrm{c}$ & $84.84 \mathrm{~b}$ & 1.49 \\
$\mathrm{NFC}^{1}$ & $22.96 \mathrm{~b}$ & $17.53 \mathrm{c}$ & $36.30 \mathrm{a}$ & $34.03 \mathrm{a}$ & 10.85 \\
NDFap $^{1}$ & $66.38 \mathrm{a}$ & $56.65 \mathrm{~b}$ & $48.18 \mathrm{c}$ & $50.81 \mathrm{c}$ & 4.91 \\
$\mathrm{iNDF}^{1}$ & $40.51 \mathrm{a}$ & $37.50 \mathrm{~b}$ & $28.82 \mathrm{c}$ & $26.83 \mathrm{c}$ & 4.71 \\
$\mathrm{ADF}^{1}$ & $42.75 \mathrm{~b}$ & $51.38 \mathrm{a}$ & $43.74 \mathrm{~b}$ & $45.10 \mathrm{~b}$ & 6.23 \\
$\mathrm{HEM}^{1}$ & $29.2 \mathrm{a}$ & $13.24 \mathrm{~b}$ & $10.64 \mathrm{~b}$ & $11.20 \mathrm{~b}$ & 12.88 \\
$\mathrm{CEL}^{1}$ & $36.64 \mathrm{~b}$ & $43.19 \mathrm{a}$ & $37.09 \mathrm{~b}$ & $38.41 \mathrm{~b}$ & 5.59 \\
$\mathrm{LIG}^{1}$ & $6.76 \mathrm{~b}$ & $8.50 \mathrm{a}$ & $5.92 \mathrm{~b}$ & $6.66 \mathrm{~b}$ & 10.54 \\
$\mathrm{TDN}^{1}$ & $54.31 \mathrm{~b}$ & $54.84 \mathrm{~b}$ & $60.51 \mathrm{a}$ & $54.93 \mathrm{~b}$ & 2.73 \\
$\mathrm{CP}^{1}$ & $4.26 \mathrm{c}$ & $22.06 \mathrm{a}$ & $9.31 \mathrm{~b}$ & $3.44 \mathrm{c}$ & 8.00 \\
$\mathrm{ADIN}^{2}(\% \mathrm{TN})$ & $9.07 \mathrm{ab}$ & $1.53 \mathrm{c}$ & $6.41 \mathrm{~b}$ & $9.70 \mathrm{a}$ & 33.87 \\
NDIN $^{2}(\% \mathrm{TN})$ & $12.94 \mathrm{~b}$ & $4.58 \mathrm{~d}$ & $8.88 \mathrm{c}$ & $19.05 \mathrm{a}$ & 20.59 \\
\hline
\end{tabular}

Means followed by equal letters in the row do not differ by Tukey's test at $5 \%$ significance.

${ }^{1}$ Percentage of dry matter; ${ }^{2}$ Percentage of total nitrogen.

No additive $=$ sugarcane silage without additive; $1 \% \mathrm{UR}=$ sugarcane silage with $1 \%$ urea; $0.5 \% \mathrm{UR}+0.5 \% \mathrm{CaO}=$ sugarcane silage with $0.5 \%$ urea $+0.5 \% \mathrm{CaO} ; 1 \% \mathrm{CaO}=$ sugarcane silage with $1 \% \mathrm{CaO} ; \mathrm{DM}=$ dry matter; $\mathrm{OM}=$ organic matter; $\mathrm{MM}=$ mineral matter; $\mathrm{CP}=$ crude protein; $\mathrm{NFC}=$ non-fibrous carbohydrates; NDFap = neutral detergent fiber corrected for ash and protein; ADF = acid detergent fiber; $\mathrm{EE}=$ ether extract; $\mathrm{HEM}=$ hemicellulose; $\mathrm{CEL}=$ cellulose; $\mathrm{LIG}=$ lignin; $\mathrm{TC}=$ total carbohydrates; $\mathrm{TDN}=$ total digestible nutrients; $\mathrm{ADIN}=$ acid detergent insoluble nitrogen, in $\% \mathrm{TN}$; NDIN = neutral detergent insoluble nitrogen, in \% $\mathrm{TN}$; $\mathrm{iNDF}=$ indigestible neutral detergent fiber.

The non-fibrous carbohydrate contents did not differ $(\mathrm{P}>0.05)$ between the silages with $1 \% \mathrm{CaO}$ (34.03\%) and with $0.5 \%$ urea $+0.5 \% \mathrm{CaO}(36.30 \%)$, and were lower $(\mathrm{P}<0.05)$ in the silages with $1 \%$ urea $(17.53 \%)$ and without additive $(22.96 \%)$.

The silage containing $1 \%$ urea showed the lowest NFC content, but this value may have been underestimated due to the high percentage of crude protein in the collected samples, resulting from the presence of the non-protein nitrogen in the silage with urea. It is also possible that the ammonia produced from the urease did not act by inhibiting the yeasts, which, in turn, consumed sucrose, with a consequent loss of nutrients. Balieiro Neto et al. (2009) found an average $28.0 \%$ NFC in sugarcane silages without additive or with $0.5 \% \mathrm{CaO}$. Thus, the use of $1 \% \mathrm{CaO}$ or the association of $\mathrm{CaO}(0.5 \%)$ with urea $(0.5 \%)$ in this study contributed favorably to the nutritive quality of the silage.

The concentration of neutral detergent fiber corrected for ash and protein did not differ $(\mathrm{P}>0.05)$ among the silages with $\mathrm{CaO}$, and it was lower $(\mathrm{P}<0.05)$ than in the silages with $1 \%$ urea and no additive, respectively. The $\mathrm{CaO}$ might have propitiated the solubilization of hemicellulose, because these same silages showed lower hemicellulose contents $(\mathrm{P}<0.05)$ in relation to that without additive. According to reports of McDonald et al. (1991), the elevation in the neutral detergent fiber content is relative and occurs due to the loss of cell content in the fermentation period. Sugarcane ensiled without additives often result in materials with high fiber contents, due to the absence of inhibition of yeasts, which are the main elements 
responsible for reduction of the cell content in these silages. It is interesting that silages present low levels of neutral detergent fiber due to its inverse correlation with dry matter intake (VAN SOEST, 1994).

Amaral et al. (2009) also observed reduction of the NDF when utilizing $1 \% \mathrm{CaO}$ or $1 \%$ (limestone) as compared with a sugarcane silage without additive. Using $0.5 \% \mathrm{CaO}$, Balieiro Neto et al. (2009) observed reduction of the NDF in relation to sugarcane silage without additive. The results found in this study corroborate the reports of Santos et al. (2009), in research with sugarcane silages without additives or with chemical additive $(1 \%$ or $1.5 \%$ $\mathrm{CaO}, 1 \%$ or $1.5 \% \mathrm{CaCO}_{3}$, and $1 \%$ gypsum). Balieiro Neto et al. (2009) found the highest NDF levels in silages without additives, and the lowest in silages with $1 \% \mathrm{CaO}$ or $1.5 \% \mathrm{CaCO}_{3}$. Therefore, according to the results found in this study and those from the abovementioned literature, it can be inferred that among the studied additives, calcium oxide was the most efficient in reducing the fiber and improving the nutritive quality of sugarcane silage (MENDES et al., 2010).

Concentrations of acid detergent fiber, cellulose and lignin were highest $(\mathrm{P}<0.05)$ for the silage with urea $(1 \%)$ and equal in the other silages $(\mathrm{P}>0.05)$. These results indicate that the silage with $1 \%$ urea did not improve the fiber quality, i.e., it did not solubilize the cell wall components. These results corroborate Lopes and Evangelista (2010), who observed the greatest ADF content in silage with the highest urea content $(1.5 \%)$. The data found in this study and by the aforementioned authors prove that the chemical additives used are not always able to solubilize the ADF components; however, hemicellulose, which is an NDF component of better nutritive value, was solubilized by $\mathrm{CaO}$, even when a lower dose $(0.5 \%)$ was used in the ensiling of sugarcane.

The TDN of the silage with $0.5 \%$ urea + $0.5 \% \mathrm{CaO}$ was greater $(\mathrm{P}<0.05)$ than in the other silages, which, in turn, did not differ $(\mathrm{P}>0.05)$. The association of the two additives - urea $(0.5 \%)$ and $\mathrm{CaO}(0.5 \%)$ - might have contributed to the higher TDN value (60.51\%) in this silage. The $\mathrm{CaO}$ probably contributed to the reduction of the losses of non-fibrous carbohydrates by the control of yeasts, in addition to having solubilized the hemicellulose, and the urea elevated the crude protein levels. Solubilization of hemicellulose is important because it allows the NDF to become more accessible to the microorganisms, i.e., the fiber provides more energy as it becomes more digestible. Furthermore, the higher levels of NFC and CP, nutrients that are also present in the equation of the total digestible nutrients, were important in obtaining this result.

There was a difference $(\mathrm{P}<0.05)$ among the silages regarding the ether extract (EE) content, which was highest in the silage with $1 \% \mathrm{CaO}$ and lowest in the silage without additive. Ether extract is a nutritional component found at low amounts in sugarcane and also in its silage, so there might have been variations in the analyses of this component.

The concentration of total carbohydrate (TC) $(\mathrm{P}<0.05)$ was highest in the silage without additive (89.33\%), which also had the highest NDF content and the lowest crude protein and ash levels. The silage with $1 \%$ urea showed a lower TC content (70.33\%), probably due to the high crude protein level of this silage.

The acid detergent insoluble nitrogen (ADIN) content was lowest $(\mathrm{P}<0.05)$ in the silage with urea $(1 \%)$ and highest in that treated with $\mathrm{CaO}(1 \%)$, just as the neutral detergent insoluble nitrogen (NDIN) content, whose results were similar. This means that the silages that were treated with urea showed the highest soluble nitrogen level in relation to those without additive or with $1 \% \mathrm{CaO}$. The difference in NDIN content between the silage without additive (control), which was smaller in relation to the silage with $1 \% \mathrm{CaO}$, may be related to the fact that $\mathrm{CaO}$ reduced the solubility of nitrogen, a nutrient of great importance in the fermentation of the feed 
in the rumen, as well as the total carbohydrates, which are sources of energy. Thus, the availability and synchronization of these nutrients to the fiberdegrading bacteria are very important for microbial protein production.

The concentration of insoluble neutral detergent fiber (iNDF) was highest in the silage without additive $(\mathrm{P}<0.05)$ and lower in the silages with $\mathrm{CaO}$, which did not differ $(\mathrm{P}>0.05)$; which was probably due the solubilization of the hemicellulose in the silages with $\mathrm{CaO}$. This outcome reinforces the feasibility of using this additive to reduce the fiber levels, which would be a nutritionally favorable characteristic to animal intake, since the sugarcane fiber has low degradability (ROMÃO et al., 2013; ROMÃO et al., 2014), which contributes to the reduction of intake due to the physical filling.
The data pertaining to the fractionation of carbohydrates (Table 3) indicate that the silages with $\mathrm{CaO}$ had a greater percentage of fraction $\mathrm{A}+\mathrm{B}^{1}$ and were statistically $(\mathrm{P}<0.05)$ superior to the silage without additive. The silage with $1 \%$ urea showed the lowest percentage of fraction $\mathrm{A}+\mathrm{B}^{1}$. Fraction $\mathrm{B}^{2}$ was higher in the silages without additive and in those with $1 \% \mathrm{CaO}$, which did not differ $(\mathrm{P}>0.05)$. However, there was a difference $(\mathrm{P}<0.05)$ between these silages and those with urea (1\% and 5\%), which presented smaller proportions of fraction $\mathrm{B}^{2}$. The silages with $\mathrm{CaO}$ had the lowest proportions of fraction $\mathrm{C}$ and did not differ $(\mathrm{P}>0.05)$. The silage without additive displayed the highest proportion of fraction $\mathrm{C}$, differing from the others $(\mathrm{P}<0.05)$, whereas the silage with $1 \%$ urea had an intermediate proportion of fraction $\mathrm{C}$.

Table 3. Fractionation of total carbohydrates into $\left(A+B^{1}\right)$, potentially soluble $\left(B^{2}\right)$ and insoluble $(C)$ carbohydrates of sugarcane silages treated with urea and calcium oxide.

\begin{tabular}{lccc}
\hline \multirow{2}{*}{ Silages } & \multicolumn{3}{c}{ Fractionation of carbohydrates (\%DM) } \\
\cline { 2 - 4 } & \multicolumn{3}{c}{ Parameter } \\
\cline { 2 - 4 } & ${\mathrm{A}+\mathrm{B}^{1}}^{1}$ & $\mathrm{~B}^{2}$ & $\mathrm{C}$ \\
\hline No additive & $22.96 \mathrm{~b}$ & $25.86 \mathrm{a}$ & $40.51 \mathrm{a}$ \\
$1 \%$ urea & $17.53 \mathrm{c}$ & $15.30 \mathrm{~b}$ & $37.50 \mathrm{~b}$ \\
$0.5 \%$ urea $+0.5 \% \mathrm{CaO}$ & $36.30 \mathrm{a}$ & $17.44 \mathrm{~b}$ & $28.82 \mathrm{c}$ \\
$1 \% \mathrm{CaO}$ & $34.03 \mathrm{a}$ & $23.97 \mathrm{a}$ & $26.83 \mathrm{c}$ \\
$\mathrm{CV}(\%)$ & 10.14 & 16.35 & 4.71 \\
\hline
\end{tabular}

Means followed by equal letters in the column do not differ by Tukey's test at $5 \%$ significance.

No additive $=$ sugarcane silage without additive; $1 \% \mathrm{UR}=$ sugarcane silage with $1 \%$ urea; $0.5 \% \mathrm{UR}+0.5 \% \mathrm{CaO}=$ sugarcane silage with $0.5 \%$ urea $+0.5 \% \mathrm{CaO} ; 1 \% \mathrm{CaO}=$ sugarcane silage with $1 \% \mathrm{CaO}$.

Among the four silages, that with $\mathrm{CaO}(1 \%)$ was superior to the others, as it showed the highest proportion of fraction $\mathrm{A}+\mathrm{B}^{1}$ - non-fibrous carbohydrates -, the highest proportion of the $\mathrm{B}^{2}$ fraction - potentially digestible fiber - , and the lowest proportion of fraction $\mathrm{C}$ - indigestible fiber. Calcium oxide provided lower losses of soluble carbohydrates and improved the fibrous components, increasing their availability, in addition to reducing the insoluble fiber (iNDF).
Azevedo et al. (2003) evaluated the fractionation of carbohydrates of three sugarcane varieties, among them SP 79-1011, utilized also in this study, and found $38.96 \%$ fraction $\mathrm{A}+\mathrm{B}^{1}, 33.26 \%$, fraction $\mathrm{B}^{2}$, and $27.78 \%$ fraction $\mathrm{C}$ for the silage treated with calcium oxide $(1 \%)$, whereas fraction $\mathrm{B}^{2}$ was found at a greater proportion in fresh sugarcane. According to the authors, this greater proportion of the $\mathrm{B}^{2}$ fraction could supply more energy to the microorganisms that ferment the fibrous and non- 
fibrous carbohydrates if this fraction had enough time to be totally degraded, which could increase the microbial protein synthesis efficiency.

It can be inferred that the use of $1 \%$ urea in the silage did not contribute to reducing the losses of soluble carbohydrates; however, when the two additives were used together $(0.5 \%$ urea $+0.5 \%$ $\mathrm{CaO})$, or $\mathrm{CaO}(1 \%)$, the silages did not differ from each other $(\mathrm{P}>0.05)$, and the percentage of fraction $\mathrm{A}+\mathrm{B}^{1}$ was higher $(\mathrm{P}<0.05)$ than that observed in the silages with $1 \%$ urea and without additives, which, in turn, contributed to reducing the losses of soluble carbohydrates.

\section{Conclusions}

Calcium oxide at the proportion of $1 \%$ during ensiling reduces the fermentation losses and the fiber content of sugarcane silage.

\section{References}

AMARAL, R. C.; PIRES, A. V.; SUSIN, I.; NUSSIO, L. G.; MENDES, C. Q.; GASTALDELLO JÚNIOR, A. L. Cana-de-açúcar ensilada com ou sem aditivos químicos: fermentação e composição química. Revista Brasileira de Zootecnia, Viçosa, v. 38, n. 8, p. 1413-1421, 2009.

AZEVEDO, J. A. G.; PEREIRA, F. C.; QUEIROZ, A. C. Q.; CARNEIRO, P. C. S. C.; LANA, R. P. L.; BARBOSA, M. H. P.; FERNANDES, A. M.; RENNÓ, F. P. Composição químico-bromatológica, fracionamento de carboidratos e cinética da degradação in vitro da fibra de três variedades de cana-de-açúcar (Saccharum spp. ). Revista Brasileira de Zootecnia, Viçosa, v. 32, n. 6, p. 1443-1453, 2003.

BALIEIRO NETO, G.; FERRARI JÚNIOR, E.; NOGUEIRA, J. R.; POSSENTI, R.; PAULINO, V. T.; BUENO, M. S. Perdas fermentativas, composição química, estabilidade aeróbica e digestibilidade aparente de silagem de cana-de-açúcar com aditivos químico e microbiano. Pesquisa Agropecuária Brasileira, Brasília, v. 44, n. 6, p. 621-630, 2009.

BALIEIRO NETO, G.; SIQUEIRA, G. R.; REIS, R. A.; NOGUEIRA, J. R.; ROTH, M. T. P.; ROTH, A. P. T. P. Óxido de cálcio como aditivo na ensilagem de cana-deaçúcar. Revista Brasileira de Zootecnia, Viçosa, v. 36, n. 5, p. 1231-1239, 2007.
CASALI, A. O.; DETMANN, E.; VALADARES FILHO, S. C. PEREIRA, J. C.; HENRIQUES, L. T.; FREITAS, S. G.; PAULINO, M. F. Influência do tempo de incubação e do tamanho de partículas sobre os teores de compostos indigestíveis em alimentos e fezes bovinas obtidos por procedimentos in situ. Revista Brasileira de Zootecnia, Viçosa, v. 37, n. 2, p. 335-342, 2008.

DETMANN, E.; PAULINO, M. F.; ZERVOUDAKIS, J. T.; VALADARES FILHO, S. C.; EUCLYDES, R. F.; LANA, R. P.; QUEIROZ, D. S. Cromo e indicadores internos na determinação do consumo de novilhos mestiços, suplementados, a pasto. Revista Brasileira de Zootecnia, Viçosa, v. 30, n. 5, p. 1600-1609, 2001.

DETMAN, E.; PINA, D. S.; VALADARES FILHO, S. C.; CAMPOS, J. M. S.; PAULINO, M. F.; OLIVEIRA, A. S.; SILVA, P. A.; HENRIQUES, L. T. Estimação da fração digestível da proteína bruta em dietas para bovinos em condições brasileiras. Revista Brasileira de Zootecnia, Viçosa, v. 35, n. 5, p. 2101-2109, 2006 c.

DETMAN, E.; VALADARES FILHO, S. C.; HENRIQUES, L. T.; PINA, D. S.; PAULINO, M. F.; MAGAlhães, A. L. R.; FIGUEIREDO, D. M.; PORTO, M. O.; CHIZZOTTI, M. L. Reparametrização do modelo baseado na lei de superfície para predição da fração digestível da fibra em detergente neutro em condições brasileiras. Revista Brasileira de Zootecnia, Viçosa, v. 36, n. 1, p. 155-164, 2007.

DETMAN, E.; VALADARES FILHO, S. C.; HENRIQUES, L. T.; PINA, D. S.; PAULINO, M. F.; VALADARES, R. F. D.; CHIZOTTI, M. L.; MAGALHÃES, K. A. Estimação da digestibilidade dos carboidratos não fibrosos em bovinos utilizando-se o conceito de entidade nutricional em condições brasileiras. Revista Brasileira de Zootecnia, Viçosa, v. 35, n. 4, p. 1479-1486, 2006a.

DETMAN, E.; VALADARES FILHO, S. C.; PINA, D. S.; CAMPOS, J. M. S.; PAULINO, M. F.; OLIVEIRA, A. S.; SILVA, P. A. Estimação da digestibilidade do extrato etéreo em ruminantes a partir dos teores dietéticos: desenvolvimento de um modelo para condições brasileiras. Revista Brasileira de Zootecnia, Viçosa, v. 35, n. 4, p. 1469-1478, 2006b.

HALL, M. B. Challenges with non-fiber carbohydrate methods. Journal of Animal Science, Champaign, v. 81, n. 12, p. 3226-3232, 2003.

JOBIM, C. C.; NUSSIO, L. G.; REIS, R. A.; SCHMIDT, P. Avancos metodologicos na avaliacao da qualidade de forragem conservada. Revista Brasileira de Zootecnia, Viçosa, v. 36, p. 101-119, 2007. Suplemento Especial. 
LOPES, J.; EVANGELISTA, A. R. Características bromatológicas, fermentativas e população de leveduras de silagem de cana-de-açúcar acrescidas de ureia e aditivos absorventes de umidade. Revista Brasileira de Zootecnia, Viçosa, v. 39, n. 5, p. 984-991, 2010.

MACIEL, S. A.; BARCELOS, B. F.; OLIVEIRA, L. A. A análise da influência da altitude na temperatura e na precipitação da mesorregião Norte de Minas Gerais. Revista Geonorte, v. 1, n. 5, p. 250-261, 2012. (Edição Especial 2)

McDONALD, P.; HENDERSON, A. R.; HERON, S. J. E. The biochemistry of silage. 2. ed. Marlow: Chalcomb Publications, 1991. 340 p.

MENDES, C. Q.; TURINO, V. F.; SUSIN, I.; PIRES, A. V.; MORAIS, J. B.; GENTIL, R. S. Comportamento ingestivo de cordeiros e digestibilidade dos nutrientes de dietas contendo alta proporção de concentrado de diferentes fontes de fibra em detergente neutro. Revista Brasileira de Zootecnia, Viçosa, v. 39, n. 3, p. 594-600, 2010.

MERTENS, D. R. Gravimetric determination of amylasetreated neutral detergent fiber in feeds with refluxing in beakers or crucibles: collaborative study. Journal of AOAC International, Gaithersburg, v. 85, n. 6, p. 1217 1240, 2002.

PEDROSO, A. F.; NUSSIO, L. G.; LOURES, D. R. S.; SANTOS, F. A. P.; MOURÃO, G. B.; BARIONI JÚNIOR, W. Efeito do tratamento com aditivos químicos e inoculantes bacterianos nas perdas e na qualidade de silagens de cana-de-açúcar. Revista Brasileira de Zootecnia, Viçosa, v. 36, n. 3, p. 558-564, 2007.

PEDROSO, A. F.; RODRIGUES, A. A.; BARIONI JÚNIOR, W.; BARBOSA, P. F.; SANTOS, F. A. P.; NUSSIO, L. G. Aditivos químicos e inoculante bacteriano na ensilagem de cana-de-açúcar: efeitos sobre a fermentação das silagens e o desempenho de garrotes. Revista Brasileira de Zootecnia, Viçosa, v. 40, n. 6, p. 1181-1187, 2011.

ROMÃO, C. O.; CARVALHO, G. G. P.; LEITE, V. M.; SANTOS, A. S.; CHAGAS, D. M. T.; RIBEIRO, O. L.; OLIVEIRA, P. A.; MAGALHÃES, A. F.; PIRES, A. J. V. Chemical composition and dry matter digestibility of sugar cane oxide treated with calcium. Arquivo Brasileiro de Medicina Veterinária e Zootecnia, Belo Horizonte, v. 66, n. 2, p. 529-538, 2014.
ROMÃO, C. O.; CARVALHO, G. G. P.; LEITE, V. M.; SANTOS, A. S.; CHAGAS, D. M. T.; RIBEIRO, O. L.; PINTO, L. F. B.; OLIVEIRA, R. L. Fracionamento de carboidratos e degradabilidade ruminal da cana-deaçúcar tratada com óxido de cálcio. Arquivo Brasileiro de Medicina Veterinária e Zootecnia, Belo Horizonte, v. 65, n. 2, p. 537-546, 2013.

SANTOS, M. C.; NUSSIO, L. G.; MOURÃO, G. B.; SCHMIDT, P.; MARI, L. J.; RIBEIRO, J. L. Influência da utilização de aditivos químicos no perfil da fermentação no valor nutritivo e nas perdas de silagem de cana-deaçúcar. Revista Brasileira de Zootecnia, Viçosa, v. 37, n. 9, p. 1555-1563, 2008.

SANTOS, M. C.; NUSSIO, L. G.; MOURÃO, G. B.; SCHMIDT, P.; MARI, L. J.; RIBEIRO, J. L.; QUEIROZ, O. C. M.; ZOPOLLATO, S. P. D.; SARTURI, J. O.; TOLEDO FILHO, S. G. Nutritive Value of sugarcane silage treated with chemical additives. Scientia Agricola, São Paulo, v. 66, n. 2, p. 159-163, 2009.

SILVA, D. J.; QUEIROZ, A. C. Análise de alimentos. Métodos químicos e biológicos. 3. ed. Viçosa: Editora UFV, 2002. 235 p.

SNIFFEN, C. J.; O'CONNOR, J. D.; VAN SOEST, P. J. FOX, D. G.; RUSSELL, J. B. A net carbohydrate and protein system for evaluating cattle diets: II. carbohydrate and protein availability. Journal of Dairy Science, Champaign, v. 70, n. 11, p. 3562-3577, 1992.

VAN SOEST, P. J. Nutritional ecology of the ruminant. 2. ed. Ithaca: Cornell University Press, 1994. 476 p.

VAN SOEST, P. J.; ROBERTSON, J. B. Analysis of forages and fibrous foods. Ithaca: Cornell University, 1985. $202 \mathrm{p}$.

ZANINE, A. M.; SANTOS, E. M.; FERREIRA, D. J.; PEREIRA, O. G.; ALMEIDA, J. C. C. Efeito do farelo de trigo sobre as perdas, recuperação da matéria seca e composição bromatológica de silagem de capimmombaça. Brazilian Journal of Veterinary Research and Animal Science, São Paulo, v. 43, n. 6, p. 803-809, 2006. 